DOI: 10.31866/2617-2674.4.2.2021.248686

UDC 654.197(477)(091)

\title{
ICONIC FACES OF UKRAINIAN TELEVISION (50-70S OF THE TWENTITH CENTURY)
}

\author{
Svitlana Kotliar ${ }^{1 a}$, Vitalii Volkov ${ }^{2 a}$ \\ ${ }^{1}$ Honored Art Worker of Ukraine, Professor of the Television Journalism and Acting Department; \\ e-mail: ilanit1925@gmail.com; ORCID: 0000-0002-4855-8172 \\ ${ }^{2}$ Master's Student at the Television Journalism and Acting Department; \\ e-mail:miller325miller@gmail.com; ORCID: 0000-0001-5263-1590 \\ ${ }^{a}$ Kyiv National University of Culture and Arts, Kyiv, Ukraine
}

\section{Keywords:}

television;

television program;

television history;

television development;

television announcer;

television space;

broadcast

For citation:

\begin{abstract}
The purpose of the research is to analyze the first steps of the television formation in Ukraine, to determine the factors of the television influence's growth on the viewer audience. The research methodology consists of the following methods: historical - analysis of sources about the first steps and development of television in Ukraine in the 50-the 70s of the twentieth century; theoretical - the factors' study of the increasing television influence on the audience. The scientific novelty of the research is the investigation of the main stages of the television space development of Ukraine in the first decades from the beginning of regular broadcasting, as well as the works of researchers of the history of Ukrainian television, have been thoroughly analyzed, the facts about the first announcers of UT have been systematized for the first time. Conclusions. In the course of the article, we proved that the technical and technological development of television in Ukraine, the growth of its influence on viewers, would have been impossible without prominent figures, representatives of various television professions who took part in the process of organizing and providing television broadcasting. The audience saw some of them on the screens, but many iconic names remained behind the scenes. The task of researchers is to identify the personas and roles of all pioneers and to preserve these names for history, for future generations.
\end{abstract}

Kotliar, S. and Volkov, V., 2021. Iconic Faces of Ukrainian Television (50-70s of the Twentith Century). Bulletin of Kyiv National University of Culture and Arts. Series in Audiovisual Art and Production, 4(2), pp.225-232.

\section{Problem statement}

One of the most important features of the modern culture of the world is the information space, which is characterized by the state of media development, especially television. This phenomenon, familiar to modern man, has very quickly 
gone a long way from live broadcasts of concerts and simple news coverage to today's TV programs for all tastes.

Today it is safe to say that television is one of the main symbols of the 20th century, which has radically changed the world. Thousands of books and articles have been written over the decades of rapid progress in television broadcasting, but interest in the history of television is only growing.

In this context, it is extremely important to find out the main stages of television development in Ukraine and to name the significant people who drove this process in the 50 s and 70 s of the last century.

\section{Recent research and publications analysis}

I. Mashchenko (1998) thoroughly studies the formation and development of Ukrainian television. It is a complete history of the invention of this technological phenomenon, the beginning and the first decades of official television broadcasting in Ukraine.

I. Mashchenko (2003) also described in detail the activities of individuals who are closely connected with the sphere of television and radio broadcasting.

A lot of valuable information is contained in the popular science publication of the group of authors "Ukrainian Television: Yesterday, Today, Tomorrow" (Chizh ed., 2006).

Z. Dmitrovskyi (2009) studied the specifics of television journalism.

The purpose of the research is to analyze the first steps in the formation of television in Ukraine. Find out the reasons for the growing influence of television on the audience.

\section{Main research material}

A well-known researcher of Ukrainian television Ivan Mashchenko (1998, p.10) mentions in his book "Television of Ukraine" notes: 'In general, the birth of the so-called "mechanical television" dates back to 1884 , which spread in 20 s-30s in many countries. Invented by the German student Paul Nipkov, a television system based on a disk with holes behind the "Archimedes spiral" - became the first stage of the practical implementation of the idea'.

November 1951 - is considered the establishment date of television in Ukraine. But the same author, referring to the encyclopedic reference book "Ukrainian Soviet Socialist Republic", cites another date: 'The article "Television and Radio Broadcasting” states: 'In 1938, a television transmitter began operating in Kiev. The principle of operation of mechanical television was based on a scanning element in the receiving and transmitting device, which was reproduced thanks to Nipkov's disks' (Mashchenko, 1998, p.38). If it can be agreed that it was an experiment, we can consider November 5, 1951 as the establishment date of the television broadcasting in Ukraine, when the first programs were broadcast from the Kyiv television center. Z. Dmitrovskyi agrees with this statement. His book "Television Journalism" mentions that Ukrainian viewers saw two films for the first time: on November 5 - "Alitet goes to the mountains" and on November 6 "Great Glow" (2009, p.15).

If to analyze the history of television according to I. Mashchenko, the Kyiv studio began its history by broadcasting samples of various art products to its viewers - cinema, theatre, pop, circus. In the beginning of television, when there were few television sets, feature films were allowed to be shown on television a week after they began to be shown in cinemas. In the 50's, immediately after the release 
of film copies from movie factories, all the newsreels were sent to the TV studio documentaries, popular science films and cartoons. In general, the share of films received from film distribution exceeded one third of the total volume of television broadcasting at that time. A prominent place at the rise of television was occupied by the theater; performances were held weekly. Music was also widely presented on TV at that time: broadcasts of opera and ballet performances, stories about the history of their origin and performances on various theatrical stages, numerous concerts. Novella Serpionova and Olha Danylenko were the first television announcers in Ukraine. Due to the fact that television was in an experimental stage, the first programs with the participation of announcers were prepared based on the radio model (Mashchenko, 1998, pp.110-111).

However, our research of archival film and video materials does not confirm the version that the famous Ukrainian radio announcer Novella Serpionova (tragically killed in a plane crash in 1982) officially worked on television. There are various sources of information that on May 1, 1952, N. Serpionova hosted a concert of the leading artists of the Taras Shevchenko Kyiv Opera House from the B TV studio. However, she could just be a guest presenter. Instead, at least two sources contain the memories of Olena Nikolaeva, who claims that she and Olha Danylenko were the first television announcers. One of these sources is an archival video of the TV program "Pryhorshcha", which was broadcast on UT-1 from the 1999 to 2001. In that video Olena Nikolaieva tells in detail about her participation in the first TV broadcasts and the experts who worked next to her. According to the members of the creative group that re- corded the conversation, O. Nikolaieva's daughter, TV director Natalia Uvarova, showed her mother's workbook, which contained a record of her work as a television announcer from 1951 to 1963 (there was a corresponding title in the Pryhorshcha TV program). In another source - an interview of 0 . Nikolaeva in the "Boulevard Gordons Boulevard" №6, (94) 2007, she notes: "There were exactly two announcers in all UT - Olha Danylenko and me." She also tells the story of how in 1951 she came to the TV studio to be hired as an assistant director, and she was immediately hired as a announcer (Kunhurtseva, 2007).

According to Ivan Mashchenko, Kyiv television in the early years was represented by only two studios on Khreshchatyk street, 26 . In 1954, a mobile TV station appeared in Kyiv, which travelled to broadcast reportage about important events. The first extracurricular program in Kyiv took place on May 30, 1954: a solemn meeting and a concert dedicated to the three centuries of the Pereiaslav Council were broadcast from the premises of the Opera House. It was a step towards the transformation of television into the means of mass communication (Mashchenko, 1998, p.112).

One can agree with I. Mashchenko that the real technological revolution took place when VCRs appeared on TV centers. In the book "Appearances and faces of television and radio space" the author notes that until the early 60's of the last century, almost all programs on Soviet television were broadcasted live. The exception was the presentation of feature and documentary films on 35 $\mathrm{mm}$ film print, which appeared on home screens from special TV sets - massive units, which, for example, in the old Kyiv TV center on Khreshchatyk street, 26 oc- 
cupied an area equivalent to almost half of the largest (270 sq $\mathrm{m}$ ) studio pavilion. However, for some time during the 50's and the 60's, some of the largest TV centers, in particular Kyiv, used a modernized cinematic method of capturing the image of the CRT screen. It was quite inconvenient, because the process was long, expensive and the result was of poor quality, because the image was gray and blurred. Although in this way many theatrical performances and concerts were filmed, where images of luminaries of the Ukrainian scene of the middle of the 20th century were recorded (Mashchenko, 2003, p.47).

In the book "Television of Ukraine" I. Mashchenko (1998, p.111) notes that the live broadcast of the 50's, which is considered to be the pride of the Ukrainian television represantatives, was almost the only form of existence of TV, because video began to enter the practice of broadcasting only in the mid-60's. At that time, television had a completely different look, unlike today. The most popular genre for viewers was cinema. Ukrainian television represantatives sought to create their own documentaries and feature films, and that is how the TV movie was created.

According to the above-mentioned author, the 1956 film adaptation of A. Chekhov's short story "The Lucky One" (directed by Y. Petrov) became the first Ukrainian feature film, but feature television did not become as well-known as a documentary television. The author also noted that the iconic face of Ukrainian documentary television was S. Zelikin. In 1958, he created the film "Our Sailor Friends". For several years at the Kharkiv studio, he continued to be the leader in Ukrainian television cinema (Mashchenko, 1998, p.114). I. Mashchenko (1998, p.126) notes that in the 1960s another achievement of science and technology had a huge impact on the development of television world - space exploration, one of the most important steps of which was television space communication. But from that moment, Ukraine did not take part in it's development, as well as other republics of the European part of the Soviet Union.

According to the authors of the popular science publication "Ukrainian Television: Yesterday, Today, Tomorrow", at the end of 1964 there were 14 program TV centers, 6 powerful and 70 small repeaters in Ukraine and there were more than 2 million TVs. These facts, as well as the accelerated construction of RL (radio relay - ed.) and cable lines (including national), created the technological preconditions for the beginning of the formation of the national television program (Chizh ed., 2006, p.108). The intensive development of most regional TV studios required the best programs to go beyond the limited borders of the regions to the national audience. On January 20, 1965 a joint nationwide program was opened at the Kharkiv Studio, which showed a report "Around the hometown" and a television program based on 0 . Arbuzov's play "And again a meeting with youth". According to the same authors, Kharkiv residents perceived this recognition of their creative activity as a step towards future participation in the UT program. Creating programs for the Ukrainian television was considered to be prestigious activity. But at that moment, technical capabilities began to lag far behind modern requirements and the reconstruction of the studio unit was carried out only in 1971 (Chizh ed., 2006, p.45).

According to I. Mashchenko, in the late 60 's colour image was invented, which 
significantly influenced the television broadcasting of that time. In 1968, the second studio unit of the telecentre was re-equipped for the production of colour programs, and in April 1969 the first colour program was aired. According to the author, the "conquest" of colour by Kyiv TV people was gradual, but persistent. First, they created a special editorial office of colour programs - "studio in studio", headed by Vladimir Agashkov. The editorial office prepared programs of almost all types and genres - from fairy tales for children to concert programs and TV shows (Mashchenko, 1998, p.125).

Meanwhile, the newly formed Ukrtelefilm studio in 1965 started shooting colour movies even earlier. The famous director R. Yefimenko created the first Ukrainian colour film "Kobzar Lived Here" in 1966, for which he was awarded many prizes (Levchuk ed, 1985, p.57).

Over the years, television started growing faster. In the 1970s, significant changes took place in the development of media space in Ukraine. Thus, I. Mashchenko $(1998, p .129)$ in the book "Television of Ukraine" notes that the March 6, 1972 - is the day of the "small television revolution" in Ukraine. At that time, two-channel television broadcasting was introduced. One group of transmitters and repeaters, as well as a separate network of radars and cable lines, was allocated to broadcast the first program of Central Television, other technical means for conducting Ukrainian television and local programs on a separate channel. The author also mentioned that the most powerful technical means were given for retransmission of the CT program in Ukraine, owing to the imperial dictates of Moscow and the position of the Central Committee of the Communist Party (Mashchenko, 1998, p.129).
The authors of the publication "Ukrainian Television: Yesterday, Today, Tomorrow" claim that the UT organization created the necessary preconditions for the transformation of Ukrainian television into a national television system. The first step was the changes in the preparation and broadcasting of information. "News" was the new information program that was organized, and regular television broadcasts of "Evening News" and "Day by Day" programs. There were 4 news programs on the air every day. In 1972, the annual volume of information materials was $1 / 5$ of the total broadcast of the Republican TV Studio - 857 hours (Chizh ed., 2006, p.116).

According to this publication, the Council of Ukrainian Television has become an important organizational and creative form of coordination and planning of programs. It consisted of the heads of the Main Directorate of Programs and Main Editions of the Republican Television, as well as regional television and radio committees. The authors note that an important place in the coordination of the creative process belonged to the General Directorate of UT programs, it was entrusted with the functions of concept development and control over all large-scale television campaigns, involvement in their implementation of editorial boards and regional committees (Chizh ed., 2006, p.123).

I. Mashchenko (1998, p.135) also noted in his book: "... the word of Ukrainian writers and folk songs sounded from the TV screen and radio dynamics, which in the extremely Russified atmosphere of that time were "small islands" of national culture". And gives an example: born in the late 70's amateur TV tournament "Solar Clarinets", whose programs were broadcast on UT for more than 20 years (Mashchenko, 1998, p.135). 
An important event of the 70's, as I. Mashchenko (2003, p.323) noted in his book "Appearences and faces of TV and Radio Space", was the opening of a new TV tower on Syrec metro station. It was built for only two years, and in August 1973 it was heared. The new Kyiv TV tower made it possible to cover a huge area with a reliable signal - more than a hundred kilometers from the capital. It became the second building in the former USSR (after Ostankino), designed to broadcast five TV programs. Two programs of the Central TV and the Ukrainian TV program were broadcast on three channels immediately.

In the publication "Television of Ukraine" I. Mashchenko mentioned that colour mobile television stations were updated MTS ("mobile television station", further "MTS"). A favorable factor for this was the XXII Olympic Games in 1980. Kyiv TV Center received new colour MTS "Magnolia", the cameras for which were developed by the French company "Thomson". About thirty Ukrainian directors, commentators, and cameramen worked in the crew of the joint creative teams at the Moscow Olympic arenas and at the Ostankino TV center. Kyiv MTS with service engineering and technical personnel, led by the director of the republican TV center V. Orkusha, provided a signal from the most important places in Luzhniki (Mashchenko, 1998, p.145).

\section{Conclusions}

At the beginning of its existence, television had a very primitive appearance, but over the years, thanks to the tireless work of domestic television, it has come a long way from simply broadcasting news to today's variety of television programs that can satisfy the most demanding tastes.

Year after year, the television space developed more rapidly. Ukrainian specialists also made a significant contribution to this progress: at the initial stage - engineers, directors, cameramen, announcers, and later - TV journalists and representatives of many other television professions.

From the initial simulation of radio (the first television announcer Olha Danylenko even greeted the people with the phrase "Hello, dear radio viewers!" - according to the archival footage we found) television broadcasting has become a state-of-theart high-tech media that has a huge impact on the audience.

\section{REFERENCES}

Chyzh, I.S. ed., 2006. Ukrainske telebachennia: vchora, sohodni, zavtra [Ukrainian television: yesterday, today, tomorrow]. Kyiv: Dyrektsiia FVD.

Dmytrovskyi, Z. I., 2009. Televiziina zhurnalistyka [Television journalism]. 3rd ed. Lviv: PAIS.

Kungurtceva, O., 2007. Pervyi diktor Ukrainskogo televideniia Elena Nikolaeva: "Ko mne blagovolil Shcherbitckii, no ego raspolozheniem ia vospolzovalas tolko raz" [The first announcer of Ukrainian television Elena Nikolaeva: "Shcherbitsky favored me, but I only used his location once"]. Bulvar Gordona, 5 February.

Levchuk, T.V., ed., 1985. Spilka kinematohrafistiv Ukrainy [Union of Cinematographers of Ukraine] Kyiv: Mystetstvo.

Mashchenko, I.H., 1998. Telebachennia Ukrainy [Television of Ukraine]. Kyiv: Tetra. Vol. 1: Telebachennia de facto [De facto television]. 
Mashchenko, I.H., 2003. Lyky i lytsia teleradioprostoru [Faces and faces of television and radio space]. Kyiv: Ukrainska Media Spilka.

\section{ЗНАКОВІ ОБЛИЧЧЯ УКРАЇНСЬКОГО ТЕЛЕБАЧЕННЯ (50-70-ті роки XX століття)}

\section{Світлана Котляр ${ }^{1 a}$, Віталій Волков²а}

1 заслужений діяч мистецтв України, професор кафедри тележурналістики та майстерності актора; e-mail: ilanit1925@gmail.com; ORCID: 0000-0002-4855-8172

${ }^{2}$ магістрант кафедри тележурналістики та майстерності актора; e-mail: miller325miller@gmail.com; ORCID: 0000-0001-5263-1590

а Київський національний університет культури і мистецтв, Київ, Україна

\section{Анотація}

Мета дослідження - проаналізувати перші кроки становлення телебачення в Україні; з'ясувати чинники зростання впливу телебачення на глядацьку аудиторію. Методологія дослідження полягає у застосуванні таких методів: історичного - для аналізу джерел про перші кроки та розвиток телебачення 50-70-х років XX ст. в Україні; теоретичного - для дослідження чинників зростання впливу телебачення на аудиторію; практичного - для роботи з архівними відеоматеріалами, що стосуються знакових постатей у розвитку телебачення в Україні. Наукова новизна: досліджено основні етапи розвитку телевізійного простору України у перші десятиліття від початку регулярного мовлення; ґрунтовно проаналізовано роботи дослідників історії українського телебачення; систематизовано факти про перших дикторів українського телебачення. Висновки. Доведено, що технічний і технологічний розвиток телебачення в Україні, зростання його впливу на глядачів були б неможливими без яскравих постатей, представників різних телевізійних професій, що брали участь у процесі організації та забезпечення телемовлення. Частину з них глядачі бачили на екранах, але чимало знакових імен залишалися за кадром. Завдання дослідників - встановити персони і ролі усіх першопрохідців і зберегти ці імена для історії, для майбутніх поколінь.

Ключові слова: телебачення; телепрограма; історія телебачення; розвиток телебачення; диктор телебачення; телевізійний простір; трансляція 


\title{
ЗНАКОВЫЕ ЛИЦА УКРАИНСКОГО ТЕЛЕВИДЕНИЯ (50-70-е годы XX века)
}

\author{
Светлана Котляр ${ }^{1 a}$, Виталий Волков ${ }^{2 a}$ \\ ${ }^{1}$ заслуженный деятель искусств Украины, \\ профессор кафедры тележурналистики и мастерства актера; \\ e-mail: ilanit1925@gmail.com; ORCID: 0000-0002-4855-8172 \\ ${ }^{2}$ магистрант кафедры тележурналистики и мастерства актера; \\ e-mail: miller325miller@gmail.com; ORCID: 0000-0001-5263-1590

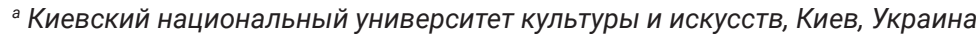

\begin{abstract}
Аннотация
Цель исследования - проанализировать первые шаги становления телевидения в Украине; определить факторы возрастания влияния телевидения на зрительскую аудиторию. Методология исследования заключается в применении таких методов: исторического - для анализа источников о первых шагах и развитии телевидения 50-70-х годов XX века в Украине; теоретического - для исследования факторов возрастающего влияния телевидения на аудиторию; практического - для работы с архивными видеоматериалами, касающимися знаковых фигур в развитии телевидения в Украине. Научная новизна: исследованы основные этапы развития телевизионного пространства Украины в первые десятилетия от начала регулярного вещания; обстоятельно проанализированы работы исследователей истории украинского телевидения; систематизированы факты о первых дикторах украинского телевидения. Выводы. Доказано, что техническое и технологическое развитие телевидения в Украине, возрастание его влияния на зрителей были бы невозможными без ярких фигур, представителей разных телевизионных профессий, принимавших участие в процессе организации и обеспечения телевещания. Часть из них зрители видели на экранах, но много знаковых имен остались за кадром. Задача исследователей - выявить персоны и роли всех первопроходцев и сберечь эти имена для истории, для будущих поколений.
\end{abstract}

Ключевые слова: телевидение; телепрограмма; история телевидения; развитие телевидения; диктор телевидения; телевизионное пространство; трансляция 